\title{
Modification of vibratory driving technology for sustainable construction works
}

\author{
Oleksandra Lohunova ${ }^{1}$ and Marek Wyjadłowski ${ }^{2, *}$ \\ ${ }^{1}$ Dnipro University of Science and Technology, av.Yawornitskiego, Dnipro, Ukraine \\ ${ }^{2}$ Wroclaw University of Science and Technology, Wyb. Wyspiańskiego 27, 50-370 Wrocław, Poland
}

\begin{abstract}
The Sustainable Development Goals were a remarkable advancement when adopted by the United Nations in 2015. For the first time, the world committed towards a wide spectrum of common goals ranging from climate action to sustainable cities from sustainable economic growth to inclusive industrialization. Sustainability is usually considered as "avoidance of the depletion of natural resources in order to maintain an ecological balance". In case of civil engineering, it means minimization of environment-related costs of ongoing project, also in terms of temporary deterioration of life quality in vicinity of building site due to noise and mechanical vibrations. Such impacts may constitute environmental load within much longer time-frame than exposure time to negative influences itself. Numerous impacts of construction work on environment, sometimes not covered by any standards, from mechanical damages to facilities and infrastructure, those which are easiest to identify, through negative influence to comfort and health of local residents, to offset the balance of nature (e.g. by chasing out birds during breeding season) are observed. The paper provides exemplary actions which may be undertaken by construction work contractors to reduce adverse dynamic impacts - mechanical vibrations, with regard to geotechnical work related to execution of deep excavation shoring. Conclusions of the paper are of general nature and, independently of rules specified by standards, they can provide guidance on good practices.
\end{abstract}

\section{Introduction - dynamic impact of foundation works}

Special geotechnical works related to modification of soil substrate [1], pile driving works [2], shoring of deep excavations [3] and earthworks including relocation of huge mass of soil are usually the stage of construction works which exert the highest environmental loading. However both mechanical vibrations and generated noise may be controlled according to respective regulations and standards [4-5]. The papers [6] and [7] provide the methodology of environmental impact monitoring together with adequate examples. In the broader context, even short-term dynamic impacts affect safety and comfort assessment as Structural Health Monitoring of buildings and structures [8-13].

\footnotetext{
* Corresponding author: marek.wyjadlowski@pwr.edu.pl
} 
Endeavours can be made to limit negative effects even when the measured levels of vibrations and noise do not exceed the admissible values $[14,15]$.

\section{Methods of dynamic impact reduction}

Considerations have been made on selected geotechnical processes how it would be possible to reduce their nuisance. In case of Rapid Impulse Compaction, it is possible to calibrate it by reducing energy of single impulse as shown in [16]. Such action can be based on on-site measurements [16] or on preliminary analysis from numerical modelling [17]. As concerns vibratory processes, the issue is a little more complicated as calibration of this technology must consist in a change of mass or frequency of vibrator, or in reduction of embedding resistance by additional actions which would allow reducing necessary energy with non-dynamic way. Efficiency of such actions is controlled by vibration velocity measurement. The paper will present examples of such actions using kits for vibration measurement placed within the soil substrate (Fig. 1a) or on structures (Fig. 1b).

a)

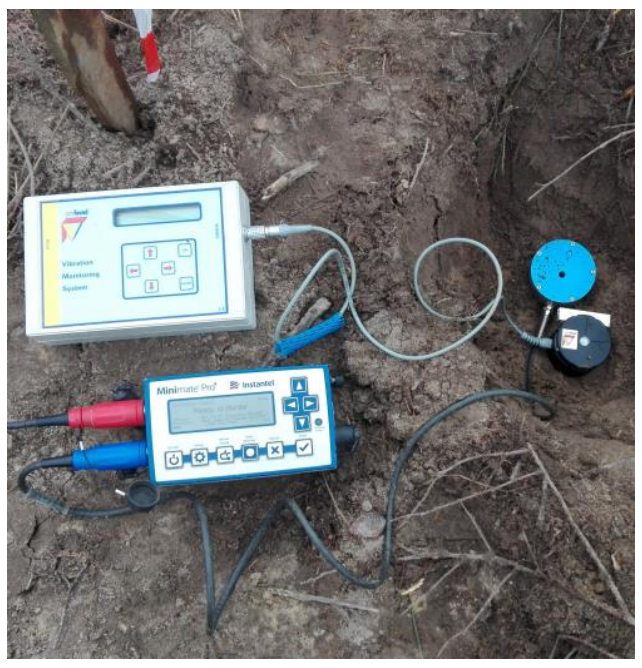

b)

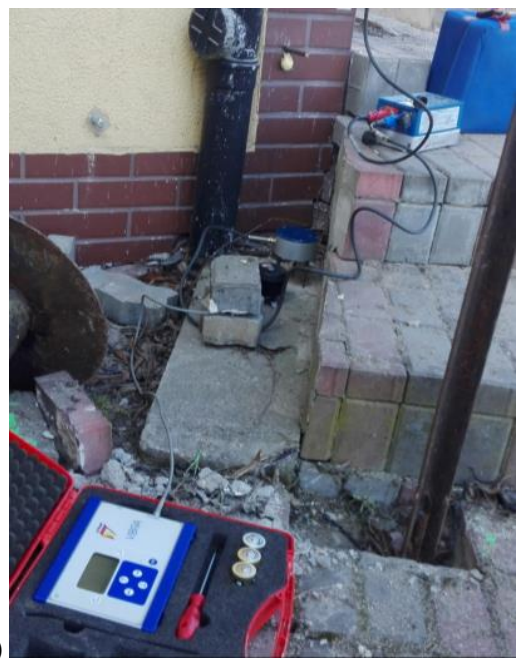

Fig. 1. Vibration control equipment: a) before "sand-bagging" in the ground, b) on the structure

\subsection{Selecting proper vibrator}

When works represent a significant risk for surroundings, like when works are run close to underground gas transmission network, both initial control and continuous monitoring of works progressed are possible. Figure 2 illustrates such three units operating on research plot in south-western Poland.

\subsection{Softening of substrate}

In order to reduce embedding resistance during driving sheet piles or piling works, by ramming or vibratory driving, pre-boring (Fig. 3) or high-pressure water-jetting at the base of steel profile being embedded (Fig.4) may be used. Each of these technologies may considerably accelerate the works and reduce energy necessary to embed steel profiles. It should, however, be remembered that destruction of natural soil structure, at the depth of profile being driven, may reduce its vertical load bearing capacity and lead to unplanned connection of aquifers. 

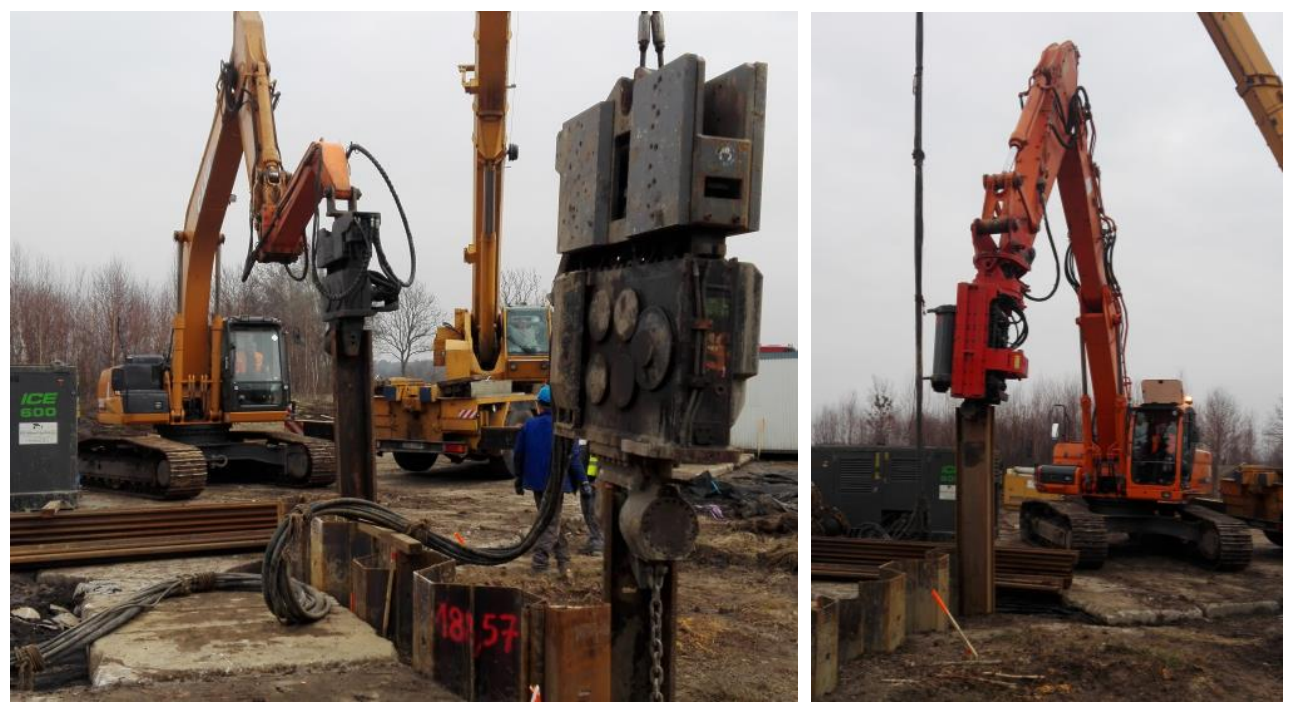

Fig.2. Testing of various equipment: a) VIB 625 and VIB 600 (ICE), b) Movax

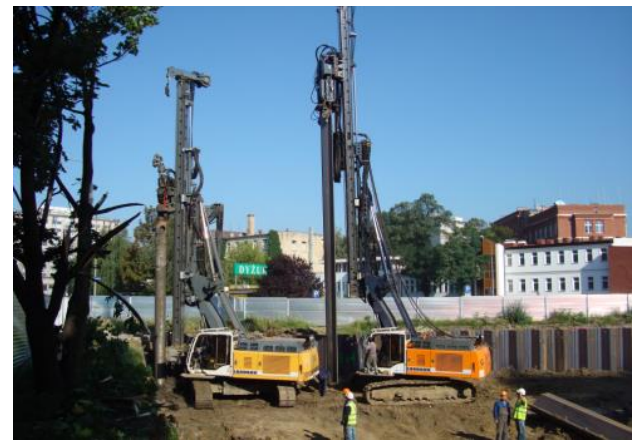

Fig. 3. Pre-boring.

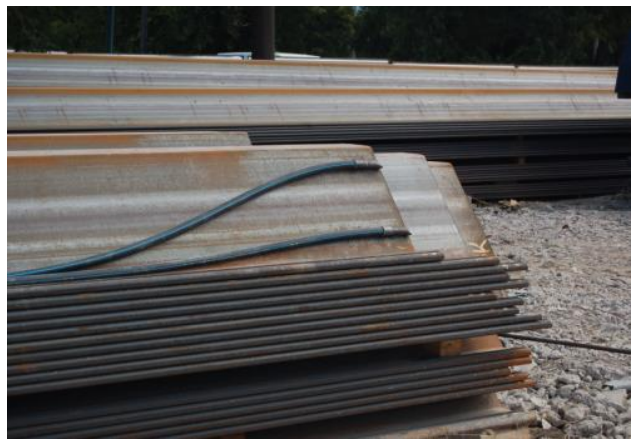

Fig. 4. Installation for "water jetting".

\section{Examples of field testing}

\subsection{Selecting proper vibrator}

During modernizing works close to gas main, it was necessary to embed steel sheet piles in close vicinity of existing and gas-filled pipeline. Monitoring was used throughout the duration of testing on March $24^{\text {th }}, 2016$ :

- Measurement of background vibrations from 12:06 to 12:21

- Operation of VIB600 vibrator at a distance c. $2 \mathrm{~m}$ from gas main from 12:22 to 12:28

- Operation of Movax vibrator at a distance c. $2 \mathrm{~m}$ from gas main from 12:33 to 12:44

- Operation of VIB600 vibrator at a distance c. $2 \mathrm{~m}$ from gas main from 13:04 to 13:09

The results given in Table 1 show that vibrator with lower power and higher frequency generated lower dynamic impacts; however the embedding time for a single sheet pile was grown nearly two-fold. It was observed on other building sites that the duration of exposure may be even more annoying for the neighbours than the vibration intensity. Hence, while deciding on technology to be used, one should balance the nuisance related to vibration level and durability of impacts. 
Table 1. Results of average Peak Particle Velocity (PPV) control within $15 \mathrm{~s}$ intervals.

\begin{tabular}{|c|c|c|c|}
\hline Action & $\begin{array}{c}\text { Vibrator } \\
\text { frequency } \\
{[\mathrm{Hz}]}\end{array}$ & $\begin{array}{c}\text { Average vibration } \\
\text { velocity } \\
{[\mathrm{mm} / \mathrm{s}]}\end{array}$ & $\begin{array}{c}\text { Duration of single pile } \\
\text { driving } \\
{[\text { minutes: seconds] }}\end{array}$ \\
\hline No operation & ------- & 0.43 & ------ \\
\hline VIB600 & $38-39$ & 9.57 & $06: 00$ \\
\hline Movax & $43-44$ & 4.74 & $11: 30$ \\
\hline VIB600 & $38-39$ & 9.47 & $05: 45$ \\
\hline
\end{tabular}

\subsection{Pre-boring efficiency}

Geotechnical conditions, prevailing at area where shoring work for deep excavation is carried out, are juxtaposed in Tab. 2. It was observed that sandy clay was very stiff and surprisingly resistant against sheet pile driving. As the main goal of the contractor was to shorten the duration of works, the ground was softened by means of pre-boring along the sheet pile line.

Table 2. Soil parameters

\begin{tabular}{|c|c|c|c|c|c|c|c|}
\hline Soil type & Thickness & $\begin{array}{c}\text { Liquidity } \\
\text { index } \\
I_{L}\end{array}$ & $\begin{array}{c}\text { Specific } \\
\text { weight } \\
\gamma\end{array}$ & $\begin{array}{c}\text { Young's } \\
\text { modulus } \\
M\end{array}$ & $\begin{array}{c}\text { Poisson's } \\
\text { ratio } \\
v\end{array}$ & $\begin{array}{c}\text { Cohesion } \\
c\end{array}$ & $\begin{array}{c}\text { Internal } \\
\text { friction angle } \\
\varphi\end{array}$ \\
\cline { 2 - 8 } & $\mathrm{m}$ & - & $\mathrm{kN} / \mathrm{m}^{2}$ & $\mathrm{MPa}$ & - & $\mathrm{kPa}$ & 0 \\
\hline $\begin{array}{c}\text { till/ } \\
\text { alluvium }\end{array}$ & 1.0 & - & & & & & \\
\hline $\begin{array}{c}\text { silty/sandy } \\
\text { clay }\end{array}$ & 1.5 & 0.15 & 21.5 & 58 & 0.29 & 41 & 24 \\
\hline sandy clay & 8.5 & 0.05 & 21.0 & 32 & 0.29 & 32 & 25 \\
\hline
\end{tabular}

The investigations were conducted at the point located about 7 meters from the edge of designed vertical excavation support system. Profiles AZ 12-700 with length $6.0 \mathrm{~m}$ were driven. Peak particle velocities in 3 directions (vertical, horizontal, and transversal) were recorded in order to be compared with limits established in DIN code [4]. Graphs presented on Fig. 5. and Fig. 6. provides information about recorded velocities without and with preboring, in time and frequency domain (respectively).
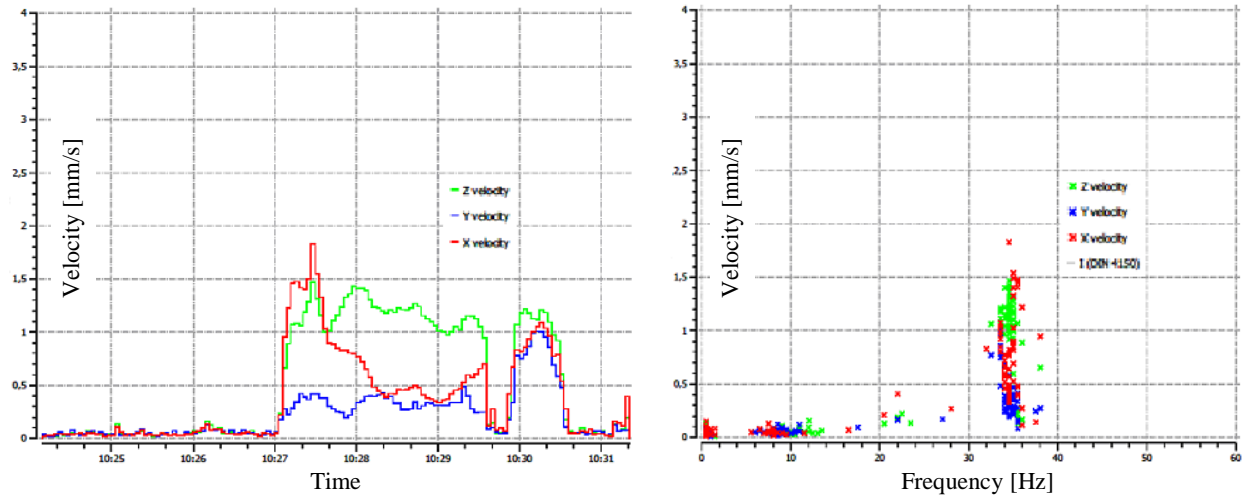

Fig. 5. Results of continuous recording of vibration velocity (without pre-boring) a) time domain, b) frequency domain 

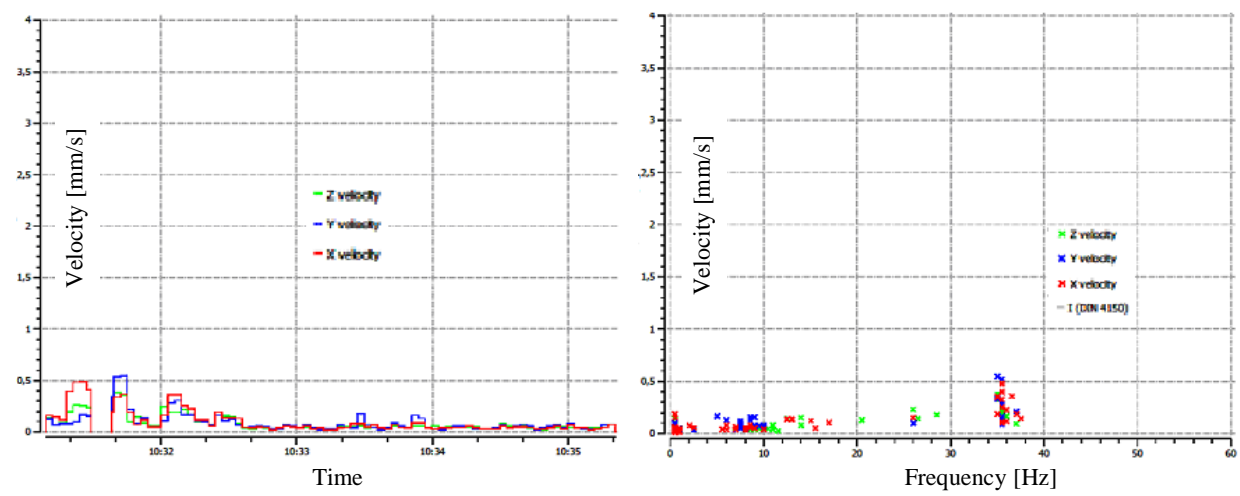

Fig. 6. Results of continuous recording of vibration velocity (after pre-boring)

a) time domain, b) frequency domain

Table 3 summarizes data from field measurements of vibration velocity for version without pre-boring and with pre-boring operation. One can see that intensity of impacts, as measured by vibration velocity on structure under monitoring, was significantly reduced (by 63\%). The embedding time for a single steel sheet pile was also significantly shortened. However, it should be borne in mind that pre-boring caused a dramatic change of soil structure in line of embedded sheet piles (increased final displacements of sheet piling wall). Also additional equipment (CFA pile driving unit) was needed to carry out the works (Fig. 3). So again, there is still a big need of some evaluation criteria based on "total footprint" of all the technologies involved.

Table 3. Estimated pre-boring efficiency by means of PPV reduction and shortened exposure time.

\begin{tabular}{|c|c|c|c|}
\hline Action & $\begin{array}{c}\text { Vibrator } \\
\text { frequency } \\
{[\mathbf{H z}]}\end{array}$ & $\begin{array}{c}\text { Average vibration } \\
\text { velocity } \\
{[\mathbf{m m} / \mathbf{s}]}\end{array}$ & $\begin{array}{c}\text { Duration of single pile } \\
\text { driving } \\
\text { [minutes:seconds] }\end{array}$ \\
\hline No operation & ------- & 0.13 & ------ \\
\hline $\begin{array}{c}\text { Without } \\
\text { pre-boring }\end{array}$ & $32-36$ & 1.10 & $6: 00$ \\
\hline $\begin{array}{c}\text { With } \\
\text { pre-boring }\end{array}$ & $36-38$ & 0.40 & $3: 30$ \\
\hline Gain [\%] & ------ & $63 \%$ & $42 \%$ \\
\hline
\end{tabular}

\section{Summary and recommendations}

Sustainable construction works are usually associated with low-emission technologies, which - on a global scale - affect carbon dioxide emission. On local level, geotechnical works affect surroundings mainly by mechanical vibrations and shock caused by transporting building materials and other construction activities. In recent years the increasing importance is also attached to the noise emitted from building site. The examples presented above show that sustainable technologies can be also implemented at construction site. However, this may be at the expense of prolonged duration and possible deteriorating the standard of construction works.

The authors would like to address their gratitude to Iwan Wyhovski Award that made it possible for Oleksandra Lohunova to work with colleagues from Wroclaw University of Science and Technology. Special thanks are also addressed to Dr Jarosław Rybak for making available field testing data for various vibratory pile driving technologies. 


\section{References}

1. F. Oliveira, I. Fernandes, Influence of geotechnical works on neighboring structures, $17^{\text {th }}$ Int. Multidisciplinary Scientific GeoConference SGEM, 17 (12), 993-1001 (2017)

2. W. Brząkała, M. Baca, The measurement and control of building vibrations in course of sheet pile wall and Franki pile driving, $17^{\text {th }}$ Int. Multidisciplinary Scientific GeoConference SGEM, 17 (12), 929-936 (2017)

3. M. Wyjadłowski, Methodology of dynamic monitoring of structures in the vicinity of hydrotechnical works - selected case studies, Studia Geotech. et Mechanica, 39 (4), 121 129, (2017)

4. DIN 4150-3:1999-02. Structural vibration Part 3: Effects of vibration on structures.

5. BS 7385-2:1993. Evaluation and measurement for vibration in buildings - Part 2: Guide to damage levels from ground borne vibration.

6. W. Brząkała, A. Herbut, J. Rybak, Recommendations for ground vibrations survey in course of geotechnical works. $14^{\text {th }}$ International Multidisciplinary Scientific GeoConference SGEM, Albena, Bulgaria, 2 (1), 747-754 (2014)

7. A. Herbut, J. Rybak, Guidelines and recommendations for vibration control in the case of rapid impulse compaction, Advances and trends in engineering sciences and technologies II, CRC Press, Taylor \& Francis Group, 761-766 (2017)

8. B. Parkasiewicz, M. Kadela, P. Bętkowski, R. Sieńko, Ł. Bednarski, Application of Structure Monitoring Systems to the Assessment of the Behaviour of Bridges in Mining Areas, IOP Conf. Ser: Mater. Sci. Eng., 245 (3), 032018 (2017)

9. V. Volkova, Monitoring Technical Conditions of Engineering Structures Using the Non-Linear Approach. IOP Conf. Ser: Mater. Sci. Eng., 96 (1), 012072 (2015)

10. R. Sieńko, Ł. Bednarski, T. Howiacki, Continuous structural health monitoring of selected geotechnical quantities within Kosciuszko Mound in Cracow, MATEC Web of Conferences, 117, 00157 (2017)

11.H. Guang, V.M. Karbhari, C.S. Sikorsky, Long-term SHM-System for a FRP Composite Highway Bridge Structure, Journal of Intelligent Material Systems and Structures, 18(8), 809-823, (2007)

12.Ł. Bednarski, R. Sieńko, T. Howiacki, Supporting Historical Structures Technical Condition Assessment by Monitoring of Selected Physical Quantities, Procedia Engineering, 195, 32-39 (2017)

13. M. Drusa, V. Cheben and R. Bulko, New technologies implemented in geotechnical monitoring on transport constructions, Int. Multidisciplinary Scientific GeoConference SGEM, 2 (1), 651-656 (2014)

14. Z. Wójcicki, S. Kostecki, J. Grosel, Operational Modal Analysis of Weir on Odra River in Poland. Procedia Engineering, 153, 874-881 (2016)

15. V. Volkova, Development of Methods for Nonparametric Identification of Models of Mechanical Systems. Procedia Engineering, 57, 1230-1235 (2013)

16. J. Rybak, A.G. Tamrazyan, Calibration of rapid impulse compaction on the basis of vibration velocity control, $16^{\text {th }}$ Int. Multidisciplinary Scientific GeoConference SGEM, 1, 715-722 (2016)

17. A. Herbut, J. Rybak, Numerical modelling of Rayleigh wave propagation in course of rapid impulse compaction, IOP Conf. Ser: Mater. Sci. Eng., 245 (3), 032001 (2017) 